University of Nebraska - Lincoln

DigitalCommons@University of Nebraska - Lincoln

Robert Powers Publications

Published Research - Department of Chemistry

1991

Secondary Structure of the Ribonuclease H

Domain of the Human Immunodeficiency Virus

Reverse Transcriptase in Solution using Three-

Dimensional Double and Triple Resonance

Heteronuclear Magnetic Resonance Spectroscopy

Robert Powers

University of Nebraska - Lincoln, rpowers3@unl.edu

G. Marius Clore

Laboratory of Chemical Physics, Building 2 National Institute of Diabetes and Digestive and Kidney Diseases National Institutes of Health, Bethesda, $M D$

Ad Bax

Laboratory of Chemical Physics, Building 2 National Institute of Diabetes and Digestive and Kidney Diseases National Institutes of Health, Bethesda, $M D$

Daniel S. Garrett

Laboratory of Chemical Physics, Building 2 National Institute of Diabetes and Digestive and Kidney Diseases National Institutes of Health, Bethesda, $M D$

Powers, Robert; Clore, G. Marius; Bax, Ad; Garrett, Daniel S.; Stahl, Stephen J.; Wingfield, Paul T.; and Gronenborn, Angela M., "Secondary Structure of the Ribonuclease H Domain of the Human Immunodeficiency Virus Reverse Transcriptase in Solution using Three-Dimensional Double and Triple Resonance Heteronuclear Magnetic Resonance Spectroscopy" (1991). Robert Powers Publications. 13.

http://digitalcommons.unl.edu/chemistrypowers/13

This Article is brought to you for free and open access by the Published Research - Department of Chemistry at DigitalCommons@University of Nebraska - Lincoln. It has been accepted for inclusion in Robert Powers Publications by an authorized administrator of DigitalCommons@University of Nebraska - Lincoln. 


\section{Stephen J. Stahl}

Protein Expression Laboratory, Building 6B Ofice of the Director, National Institutes of Health Bethesda, MD

See next page for additional authors

Follow this and additional works at: http:// digitalcommons.unl.edu/chemistrypowers 
Authors

Robert Powers, G. Marius Clore, Ad Bax, Daniel S. Garrett, Stephen J. Stahl, Paul T. Wingfield, and Angela M. Gronenborn 


\title{
Secondary Structure of the Ribonuclease H Domain of the Human Immunodeficiency Virus Reverse Transcriptase in Solution using Three-Dimensional Double and Triple Resonance Heteronuclear Magnetic Resonance Spectroscopy
}

\author{
Robert Powers $^{1}$, G. Marius Clore ${ }^{1} \dagger$, Ad Bax ${ }^{1}$, Daniel S. Garrett ${ }^{1}$, Stephen J. Stahl ${ }^{2}$ \\ Paul T. Wingfield ${ }^{2}$ and Angela M. Gronenborn ${ }^{1} \dagger$
}

\author{
${ }^{1}$ Laboratory of Chemical Physics, Building 2 \\ National Institute of Diabetes and Digestive and Kidney Diseases \\ National Institutes of Health, Bethesda, MD 20892, U.S.A. \\ ${ }^{2}$ Protein Expression Laboratory, Building $6 B$ \\ Office of the Director, National Institutes of Health \\ Bethesda, MD 20892, U.S.A.
}

(Received 13 June 1991; accepted 11 July 1991)

\begin{abstract}
The solution structure of the ribonuclease $H$ domain of $H I V-1$ reverse transcriptase has been investigated by three-dimensional double and triple resonance heteronuclear magnetic resonance spectroscopy. The domain studied has 138 residues and comprises residues 427 to 560 of the $66 \mathrm{kDa}$ reverse transcriptase with an additional four residues at the $\mathrm{N}$ terminus. Initial studies on the wild-type protein were hindered by severe differential line broadening, presumably due to conformational averaging. Mutation of the single tryptophan residue located in a loop at position 113 (position 535 in the reverse transcriptase sequence) to an alanine resulted in much improved spectral properties with no apparent change in structure. ${ }^{1} \mathrm{H},{ }^{15} \mathrm{~N}$ and ${ }^{13} \mathrm{C}$ backbone resonances were assigned sequentially using a range of threedimensional double and triple resonance heteronuclear experiments on samples of uniformly $(>95 \%)^{15} \mathrm{~N}$ and ${ }^{15} \mathrm{~N} /{ }^{13} \mathrm{C}$-labeled protein, and the secondary structure was elucidated from a qualitative analysis of data derived from three-dimensional ${ }^{15} \mathrm{~N}$-and ${ }^{13} \mathrm{C}$-edited nuclear Overhauser enhancement spectra. The secondary structure comprises three $\alpha$-helices and five strands arranged in a mixed parallel/antiparallel $\beta$-sheet with $a+1,+1,-3 x,-1 x$ topology. The C-terminal region from residue 114 onwards appears to be conformationally disordered in solution as evidenced by an almost complete absence of sequential and medium range nuclear Overhauser effects.
\end{abstract}

Key words: HIV-1; RNase H domain; reverse transcriptase; solution secondary structure; $3 \mathrm{D}$ heteronuclear n.m.r.; double and triple resonance n.m.r.

The ribonuclease $H$ (RNase $H_{+}^{+}$) domain of human immunodeficiency virus $(\mathrm{HIV}-1)$ reverse transcriptase plays a crucial role in viral replication as evidenced by the failure of mutant provirus, defective for RNase $H$ function, to produce infective virus particles (Schatz et al.. 1989). The RNase $H$ domain catalyses the cleavage of the RNA portion of a DNA/RNA hybrid, a process that is $\dagger$ Authors to whom all correspondence should be addressed.

$\ddagger$ RNase $\mathrm{H}$, the ribonuclease $\mathrm{H}$ domain comprising residues 427 to 560 of the $66 \mathrm{kDa}$ reverse transcriptase of HIV-1 together with the four amino acid sequence Met-Asn-Glu-Leu at the $\mathrm{N}$ terminus; HIV-1, human immunodeficiency virus-1; AIDS, acquired immunodeficiency syndrome; n.m.r. nuclear magnetic resonance; NOE, nuclear Overhauser effect; NOESY. nuclear Overhauser enhancement spectroscopy;
HOHAHA, homonuclear Hartmann-Hahn spectroscopy; 3D, three-dimensional; $\mathrm{HNCO}$, amide proton to nitrogen to carbonyl correlation; HNCA, amide proton to nitrogen to $\alpha$-carbon correlation; $\mathrm{HN}(\mathrm{CO}) \mathrm{CA}$. amide proton to nitrogen (via carbonyl) to $\alpha$-carbon correlation; HCACO, alpha-proton to $\alpha$-carbon to carbonyl correlation; $\mathrm{HCA}(\mathrm{CO}) \mathbf{N}, \alpha$-proton to $\alpha$-earbon (via carbonyl) to nitrogen correlation: e.d., circular dichroism; p.p.m., parts per million; 2D. two-dimensional. 


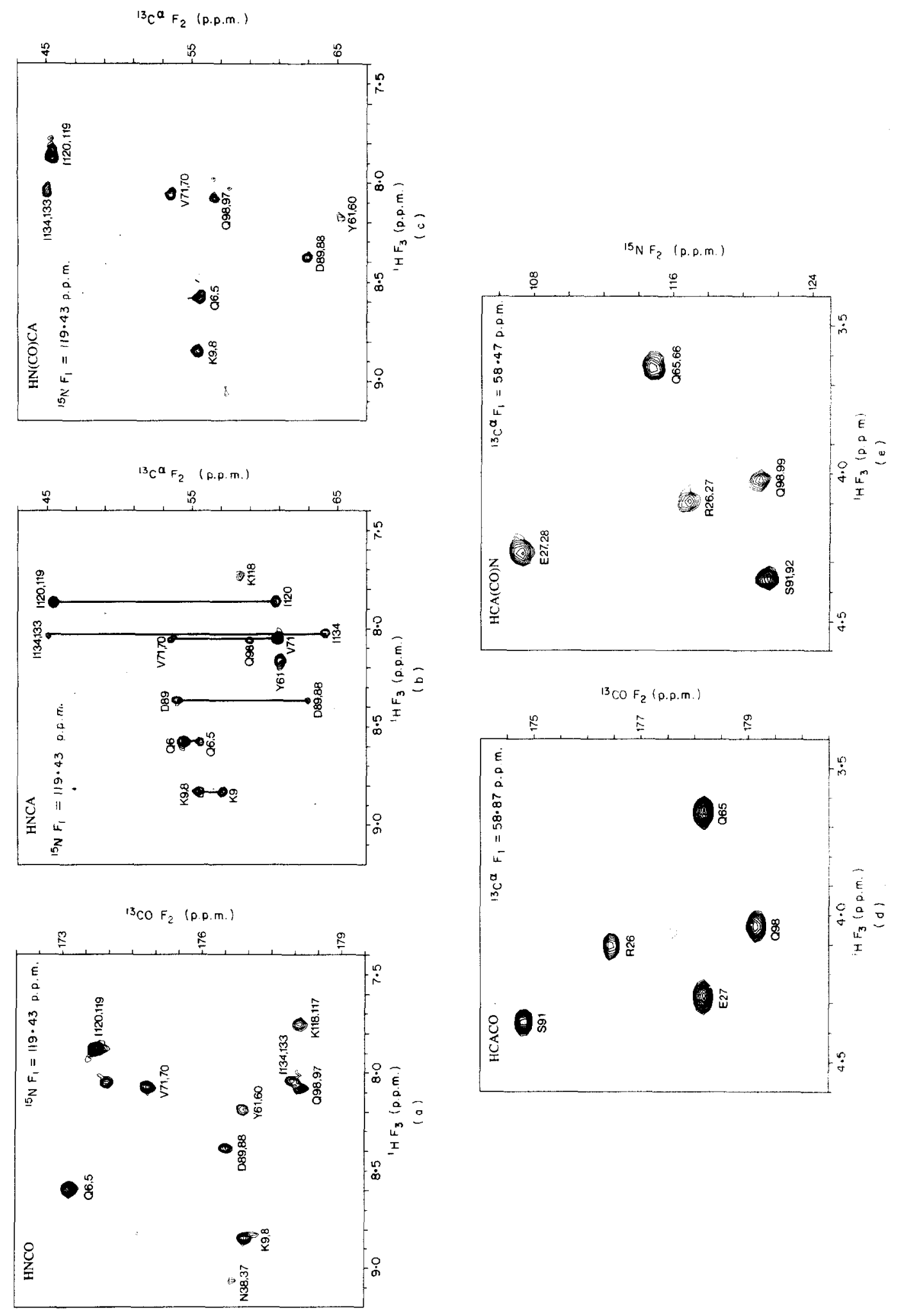




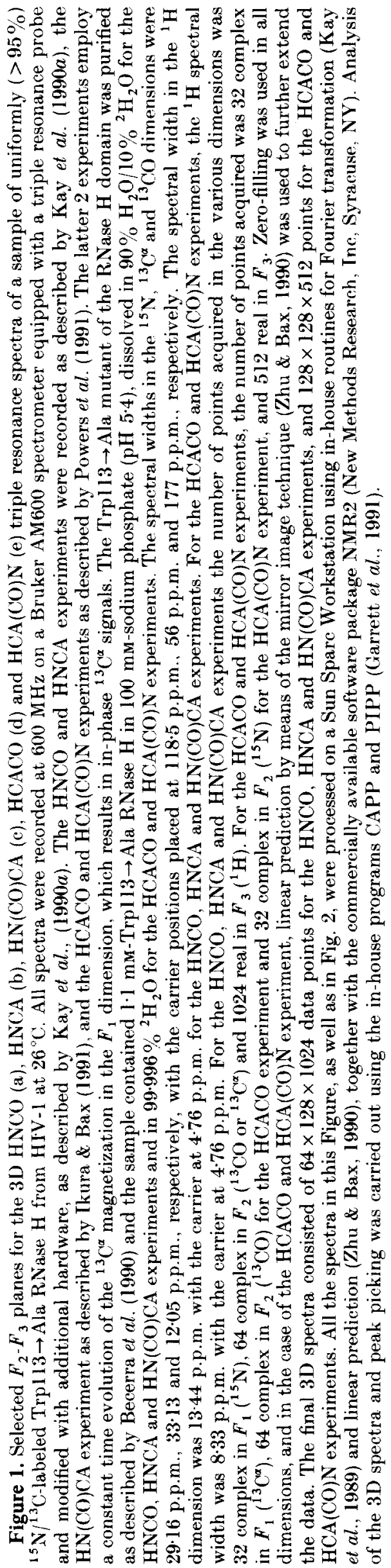


required at several stages during reverse transcrip tion, and displays both endonuclease and $3^{\prime} \rightarrow 5^{\prime}$ exonuclease activity (Krug \& Berger, 1989; Mizrahi, 1989; Schatz et al., 1990). Thus, the RNase H domain presents a potential site for the design of drugs for the treatment of AIDS (Mitsuya et al. 1990). In a recent paper we described the overexpression, purification and physical character ization of the RNase $\mathrm{H}$ domain comprising residues 427 to 560 of the $66 \mathrm{kDa}$ reverse transcriptase with an additional four residue sequence at the $\mathrm{N}$ terminus (Becerra et al., 1990). In this paper we present initial multi-dimensional heteronuclear studies on the RNase $H$ domain undertaken with the eventual aim of determining its high-resolution three-dimensional structure in solution. Specifically, the backbone ${ }^{1} \mathrm{H},{ }^{15} \mathrm{~N}$ and ${ }^{13} \mathrm{C}$ resonances are assigned in a sequential manner using a combination of $3 \mathrm{D}$ double and triple resonance heteronuclear n.m.r. experiments, and the secondary structure is elucidated from a qualitative analysis of NOE connectivities derived from $3 \mathrm{D}$ heteronuclearedited NOESY spectra (for reviews, see Clore \& Gronenborn 1991 $a, b, c)$. As the work presented in this paper was being prepared for publication, a $2.4 \AA(1 \AA=0.1 \mathrm{~nm})$ resolution $X$-ray structure of RNase $H$ from a different $H I V-1$ virus strain was published (Davies et al., 1991). The results from both studies are essentially in agreement, although significant differences are noted at the $\mathrm{C}$ terminus.

Thitially n.m.r. studies were carried out on the wild-type RNAse $H$ domain from strain $\mathrm{HXB} 2$ of HIV-l. However, it rapidly became apparent that the assignment procedure was being impaired by suspected conformational exchange processes. Thus, we were unable to see many connectivities in the various $3 \mathrm{D}$ triple resonance experiments due to severe line broadening. This was also manifested in the 3I) ${ }^{15} \mathrm{~N}$-edited NOESY (Fesik \& Zuiderweg, 1988; Marion et $a l,, \quad 1989 a, b)$ and HOHAIIA (Marion et al., 1989b; Driscoll et al., 1990a; Clore et al., 1991) spectra, as well as in the $2 \mathrm{D}{ }^{1} \mathrm{H}-{ }^{15} \mathrm{~N}$ and ${ }^{1} \mathrm{H}-{ }^{13} \mathrm{C}$ correlation spectra (Bodenhausen \& Ruben, 1980; Bax et al., 1990a). In the latter spectra, a large variation in cross-peak intensities occurred. At a very early stage of this work, we found that, under all eonditions tried, we did not observe the ${ }^{1} \mathrm{H}{ }^{13}$ ( correlations for the aromatic ring of the single Trp residue at position 113 , while those for the other eight aromatic rings ( $6 \mathrm{Tyr}, \mathrm{l}$ Phe and $1 \mathrm{His}$ ) were clearly detectable. We therefore postulated that Trp113 was located in a segment of the polypeptide chain that exhibited conformational flexibility, resulting in severe line broadening of adjacent protons through large differences in ring current shifts between the conformers. On the basis of this hypothesis, we proceeded to construct a Trpll3 $\rightarrow$ Ala mutant by primer-directed mutagenesis (Oostra et al., 1983). No difference in stability of the native and mutant proteins was found, both of which had a $T_{\mathrm{m}}$ of $\sim 60^{\circ} \mathrm{C}$ (determined by differential scanning calorimetry), and the location of many of the cross-peaks in the ${ }^{1} \mathrm{H}-{ }^{15} \mathrm{~N}$ correlation spectra of the two proteins were identical. Further, there was little difference in the c.d spectrum of the two proteins. This implied that the mutation caused only minimal structural perturbation, which would be entirely consistent with the predicted location of Trpl 13 on the protein surface based on sequence alignment with the known crystal structure of Escherichia coli RNase H (Yang et al., 1990; Katayanagi et al., 1990). However, the spectra of the mutant enzyme were both qualitatively and quantitatively vastly superior to those of the wild-type protein, so that further detailed study was restricted to the mutant.

The sequential assignment strategy was based on a series of $3 \mathrm{D}$ double and triple resonance n.m.r experiments. In particular, we made use of five triple resonance experiments to establish connectivities along the chain via one- and two-bond heteronuclear couplings. The 3D HNCO, HNCA (Ikura et $a l ., 1990 a$ ) and HN(CO)CA (Ikura \& Bax, 1991) experiments recorded in water were used to establish $\quad \mathrm{NH}(i)-{ }^{15} \mathrm{~N}(i)-{ }^{13} \mathrm{CO}(i-1), \quad \mathrm{NH}(i)-{ }^{15} \mathrm{~N}(i)-$ ${ }^{13}\left(\mathrm{C}^{\alpha}(i, i-1)\right.$ and $\mathrm{NH}(i)-{ }^{15} \mathrm{~N}(i)-{ }^{13} \mathrm{C}^{\alpha}(i-1)$ correlations. respectively. ${ }^{13} \mathrm{C}\left(F_{2}\right)-\mathrm{NH}\left(F_{3}\right)$ planes of these three experiments at a single ${ }^{15} \mathrm{~N}\left(F_{1}\right)$ frequency of 119.43 p.p.m. are illustrated in Figure $1(a)$ to $(c)$. As the ${ }^{15} \mathrm{~N}-{ }^{13} \mathrm{C}^{\alpha}$ intraresidue one-bond coupling is larger than the interresidue two-bond coupling, it is usually the case that the intraresidue correlations in the HNCA experiment are more intense than the interresidue ones (Clore et al., 1990; Kay et al. $1990 b)$. However, in the case of RNase $H$ where complications arise from exchange line broadening this rule is not generally applicable. Thus, for example, the interresidue correlations for Lys 9 and Ilel 20 seen in Figure 1(a) are actually more intense than the intraresidue ones. Possible ambiguities are resolved by analysis of the $\mathrm{HN}(\mathrm{CO}) \mathrm{CA}$ spectrum, which only displays the interresidue ${ }^{13} \mathrm{C}^{\alpha}(i-1)-{ }^{15} \mathrm{~N}(i)$ correlations. The 3D IICACO and IICA(CO)N experiments (Ikura et al. 1990a; Powers et al., 1991) recorded in ${ }^{2} \mathrm{H}_{2} \mathrm{O}$ were used to establish $\mathrm{C}^{\alpha} \mathrm{H}(i)-{ }^{13} \mathrm{C}^{\alpha}(i)-{ }^{13} \mathrm{CO}(i)$ and $\mathrm{C}^{\alpha} \mathrm{H}(i)-{ }^{13} \mathrm{C}^{1 \alpha}(i)-{ }^{15} \mathrm{~N}(i+1)$ correlations, respectively. These experiments are illustrated in Figure $\mathrm{l}(\mathrm{d})$ to $(\mathrm{e})$, which show a set of ${ }^{13} \mathrm{CO}\left(F_{2}\right)-\left({ }^{\alpha} \mathrm{H}\left(F_{3}\right)\right.$ and ${ }^{15} \mathrm{~N}\left(F_{2}\right)-{ }^{\alpha} \mathrm{H}\left(F_{3}\right)$ planes at the same ${ }^{13} \mathrm{C}\left(F_{1}\right)$ frequency of 58.87 p.p.m. In addi tion, a $3 \mathrm{I})^{15} \mathrm{~N}$-edited HOHAHA spectrum recorded in $\mathrm{H}_{2} \mathrm{O}$ with a DIPSI-2 mixing scheme (Clore et al. 1991) was used to identify ${ }^{15} \mathrm{~N}(i)-\mathrm{NH}(i)-\mathrm{C}^{\alpha} \mathrm{H}(i)$ correlations (Fig. 2(a)). Interpretation of these six scalar correlation experiments is sufficient to sequentially assign the backbone ${ }^{1} \mathrm{H},{ }^{15} \mathrm{~N}$ and ${ }^{13}{ }^{1}$ resonances. Confirmation of the sequential assignment was based on $3 \mathrm{D}^{15} \mathrm{~N}$ and ${ }^{13} \mathrm{C}$-edited (Ikura et al., 1990b; Zuiderweg et al. 1990) NOESY spectroscopy to identify through-space $(<5 x)$ connectivities of the type $\mathrm{NH}(i)-\mathrm{NH}(i+1,2)$ $\mathrm{C}^{\alpha} \mathrm{H}(i)-\mathrm{NH}(i+1,2,3,4), \quad \mathrm{C}^{\beta} \mathrm{H}(i)-\mathrm{NH}(i+1), \quad \mathrm{C}^{\alpha} \mathrm{H}(i)$ $\mathrm{C}^{\beta} \mathrm{H}(i+3)$. which have been extensively used in conventional protein resonance assignment by $2 \mathrm{D}$ ) methods (Wüthrich, 1986; Clore \& Gronenborn. 1987). Examples of selected amide strips through 


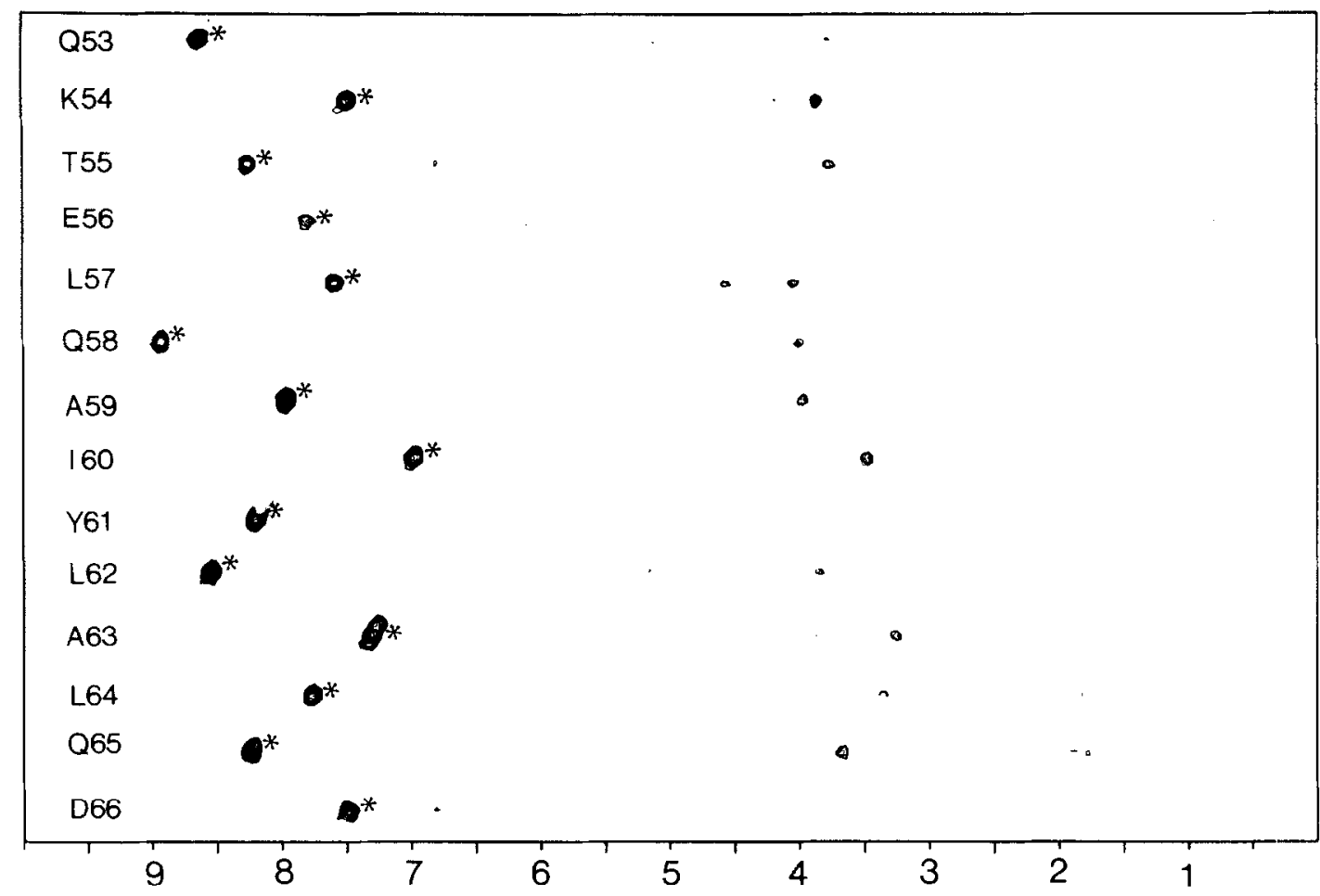

(b) $15 \mathrm{~N}$-edited NOESY

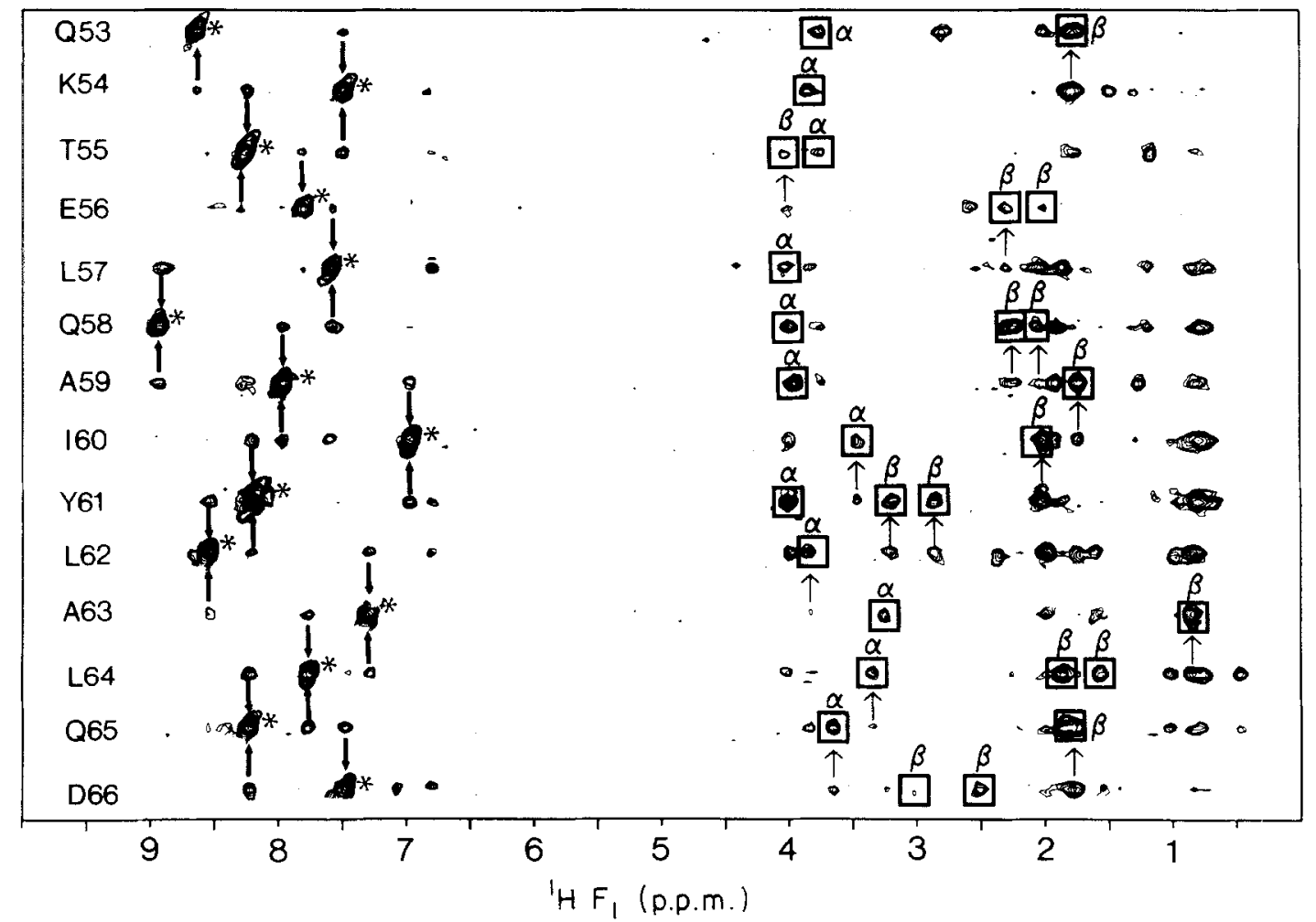

Figure 2. Amide strips extending from GIn53 to Asp66 taken from the $600 \mathrm{MHz} 3 \mathrm{D}{ }^{15} \mathrm{~N}$-edited HOHAHA (a) and NOESY (b) spectra of uniformly ( $>95 \%$ ) ${ }^{15} \mathrm{~N}$-labeled Trpl $13 \rightarrow$ Ala RNase $\mathrm{H}$ from HIV-l recorded at $26^{\circ} \mathrm{C}$. The mixing times for the 2 experiments were $30 \mathrm{~ms}$ and $100 \mathrm{~ms}$, respectively, and the experiments were recorded as described by Clore et al. (1991) and Driscoll et al. (1990a), respectively. The Figure is composed of narrow strips taken from different ${ }^{1} \mathrm{H}\left(F_{1}\right)-\mathrm{NH}\left(F_{3}\right)$ planes of the 3D spectrum, as described by Driseoll et al. $(1990 a)$. Asterisks indicate the position of the diagonal peak for each residue and boxes enclose the intraresidue $\mathrm{NH}-\mathrm{C}^{\alpha} \mathrm{H}$ and $\mathrm{NH}-\mathrm{C}^{\beta} \mathrm{H}$ cross-peaks observed in the NOESY spectrum. Sequential NH-NH(i+1) NOEs are indicated by thick arrows, sequential $\mathrm{C}^{\alpha} \mathrm{H}(i)-\mathrm{NH}(i+1)$ and ${ }^{\beta} \mathrm{H}(i)-\mathrm{NH}(i+1) \mathrm{NOEs}$ with thin arrows. Note that while the $\mathrm{NH}-\mathrm{C}^{\alpha} \mathrm{H}$ cross peaks in the HOHAHA spectrum are observed for all the residues in this Figure (with the exception of Glu56, Tyr6l and Asp66), $\mathrm{NH}-\mathrm{C}^{\beta} \mathrm{H}$ cross-peaks are only seen for Gln65 and Asp66 and these are of very weak intensity. The spectral widths in the $F_{1}\left({ }^{1} \mathrm{H}\right), F_{2}\left({ }^{15} \mathrm{~N}\right)$ and $F_{3}\left({ }^{1} \mathrm{H}\right)$ dimensions were $11 \cdot 41$ p.p.m., $29 \cdot 16$ p.p.m. and 13.44 p.p.m. with the carrier placed at 118.5 p.p.m. in the ${ }^{15} \mathrm{~N}$ dimension and at 4.76 p.p.m. in the ${ }^{1} \mathrm{H}$ dimensions. The total number of points acquired were 128 complex in $F_{1}\left({ }^{1} \mathrm{H}\right), 32$ complex in $F_{2}\left({ }^{15} \mathrm{~N}\right)$ and 1024 real in $F_{3}\left({ }^{1} \mathrm{H}\right)$, and the final absorptive part of the 3D spectra, after appropriate zero-filling, consisted of $256 \times 64 \times 1024$ points. 

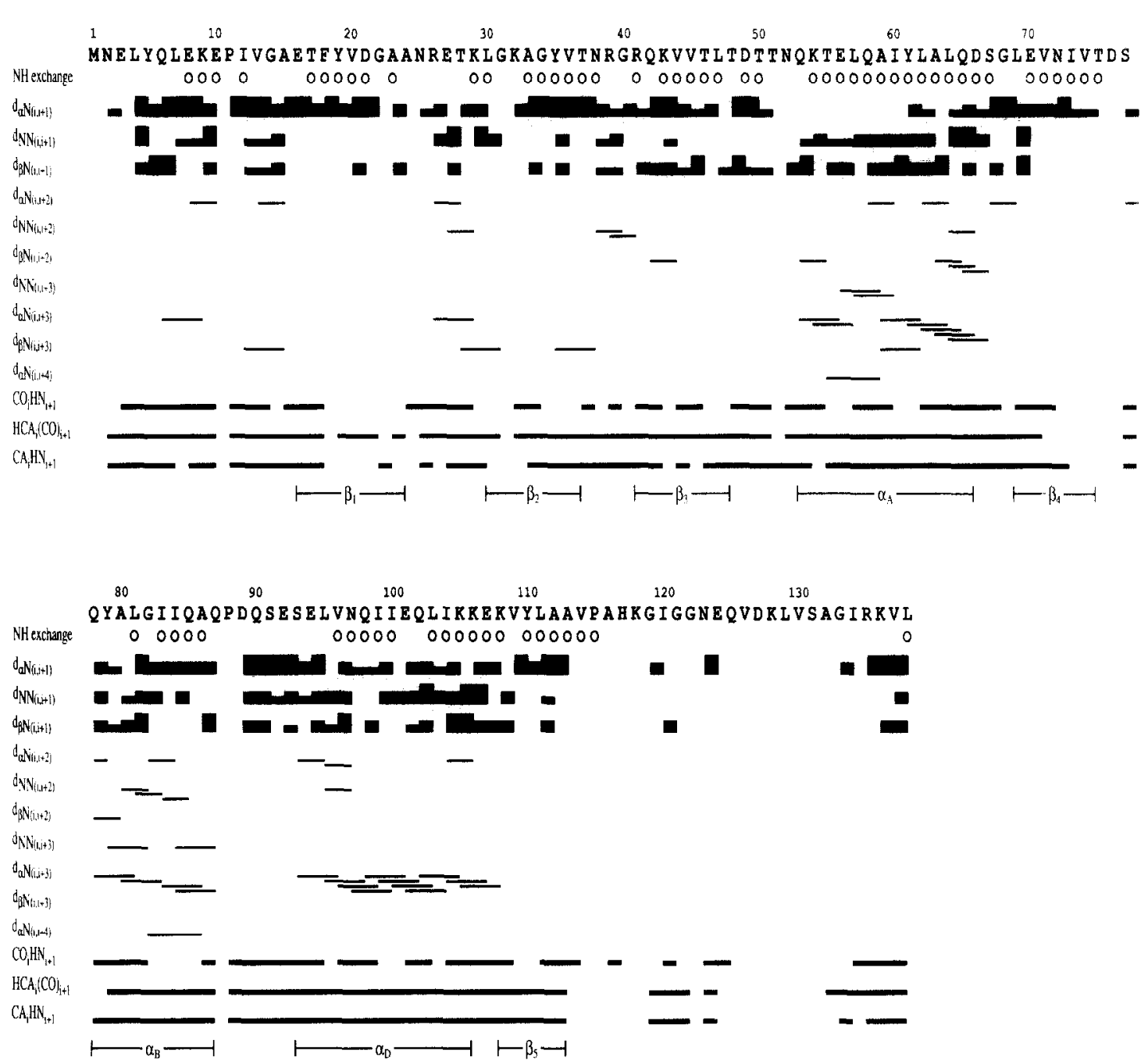

Figure 3. Summary of the sequential scalar connectivities observed in the 3D triple resonance experiments and the sequential and medium (up to $i, i+4$ ) range through-space connectivities observed in the $3 D$ heteronuclear-edited NOESY spectra for Trpl13 $\rightarrow$ Ala RNase $\mathrm{H}$ from HIV-I. The NOE intensities are classified into strong, medium and weak, according to the thickness of the lines. Slowly exchanging amide protons are indicated by open circles, and the elements of regular secondary structure are displayed at the bottom of the Figure. The sequence of the RNase $H$ domain starts at Tyr5, which corresponds to residue 427 of the $66 \mathrm{kDa}$ HIV-1 reverse transcriptase.

the ${ }^{15} \mathrm{~N}$-edited NOESY spectrum (Driscoll et al., $1990 a, b)$ are shown in Figure $2(\mathrm{~b})$, which displays, the sequential NOE connectivities observed along the segment of chain extending from Gln53 to Asp66, corresponding to helix $\alpha_{\mathrm{A}}$. Finally, spin systems were identified, where possible, using $3 \mathrm{D}$ HCCH-COSY and HCCH-TOCSY experiments that establish scalar connectivities along the chain via the one-bond ${ }^{1} \mathrm{H}-{ }^{13} \mathrm{C}$ and ${ }^{13} \mathrm{C}-{ }^{13} \mathrm{C}$ couplings (Bax et $a l ., 1990 b, c$; Clore et al., 1990; Kay et al., 1990a).

A summary of the sequential scalar and the sequential and medium range (up to $i, i+4) \mathrm{NOE}$ connectivities observed for the Trp1 $13 \rightarrow$ Ala mutant of RNase $\mathrm{H}$ domain is shown in Figure 3, and the backbone ${ }^{1} \mathrm{H},{ }^{15} \mathrm{~N}$ and ${ }^{13} \mathrm{C}$ assignments are given in Table 1. We were able to confidently obtain backbone resonance assignments for 123 of the 138 residues for the mutant protein compared to 110 tentative assignments for the wild-type. The number of residues for which a complete set of correlations was observed in the triple resonance experiments and the ${ }^{15} \mathrm{~N}$-edited HOHAHA spectrum was 60 for the mutant compared to only 31 for the wild-type. Further NOEs involving $113 \mathrm{NH}$ protons could be assigned in the $3 D^{15} \mathrm{~N}$-edited NOESY spectrum of the mutant compared to only 86 for the wild-type. It is also interesting to note that with the exception of Metl and Asp76, almost all residues in the mutant protein for which no backbone assignments could be ascertained are located in the $\mathrm{C}$ terminus, whereas in the wild-type unassigned residues are spread throughout the sequence.

The secondary structure was deduced from a qualitative analysis of the NOE data involving the backbone $\mathrm{NH}, \mathrm{C}^{\alpha} \mathrm{H}$ and $\mathrm{C}^{\beta} \mathrm{H}$ protons (Wüthrich, 1986; Clore \& Gronenborn, 1987) derived from the $3 \mathrm{D}{ }^{15} \mathrm{~N}$ - and ${ }^{13} \mathrm{C}$-edited NOESY spectra, in conjunction with data on slowly exchanging amide protons (summarized in Fig. 3). The latter was 
Table 1

Backbone ${ }^{1} \mathrm{H},{ }^{13} \mathrm{C}$ and ${ }^{15} \mathrm{~N}$ resonance assignments for the $R N a$ se $H$ domain of $H I V-1$ reverse transcriptase at $p H 5 \cdot 4$ and $26^{\circ} \mathrm{C}$

\begin{tabular}{|c|c|c|c|c|c|}
\hline & & Che & al shift & o.p.m. & \\
\hline & ${ }^{15} \mathrm{~N}$ & ${ }^{13} \mathrm{C}^{\alpha}$ & ${ }^{13} \mathrm{CO}$ & NH & $\mathrm{C}^{\alpha} \mathbf{H}$ \\
\hline Met] & -- & - & - & - & - \\
\hline Asn 2 & -- & $53 \cdot 6$ & 176.5 & - & $5 \cdot 14$ \\
\hline Glu3 & $114 \cdot 8$ & $56 \cdot 8$ & $176 \cdot 5$ & $8 \cdot 42$ & $4 \cdot 22$ \\
\hline I.en14 & $121 \cdot 5$ & $55 \cdot 8$ & $176 \cdot 1$ & $8 \cdot 49$ & $4 \cdot 28$ \\
\hline Tyr5 & $113 \cdot 9$ & $55 \cdot 7$ & $173 \cdot 1$ & $7 \cdot 18$ & $4 \cdot 71$ \\
\hline Gin6 & $119 \cdot 3$ & $54 \cdot 5$ & $174 \cdot 7$ & 8.58 & $4: 55$ \\
\hline Leu7 & $123 \cdot 9$ & 53.9 & $178 \cdot 0$ & 8.55 & 4.93 \\
\hline Glu8 & $121 \cdot 5$ & $55 \cdot 7$ & $176 \cdot 9$ & $9 \cdot 06$ & $4 \cdot 29$ \\
\hline Lys9 & $119 \cdot 4$ & $57 \cdot 3$ & $176 \cdot 0$ & $8 \cdot 84$ & $4 \cdot 44$ \\
\hline Glu 10 & $116 \cdot 8$ & $53 \cdot 0$ & $171 \cdot 8$ & $7 \cdot 55$ & $4 \cdot 59$ \\
\hline Proll & $\ldots$ & $62 \cdot 4$ & $175 \cdot 7$ & - & - \\
\hline Ilel 2 & 1250 & $61 \cdot 2$ & $178 \cdot 3$ & $9 \cdot 43$ & $3 \cdot 88$ \\
\hline Vall3 & $132 \cdot 3$ & $65 \cdot 1$ & $177 \cdot 4$ & $8 \cdot 69$ & $3 \cdot 65$ \\
\hline Glyl4 & $114 \cdot 4$ & $45 \cdot 1$ & $173 \cdot 4$ & $8 \cdot 79$ & - \\
\hline Alal5 & $121 \cdot 6$ & $50 \cdot 6$ & 176.5 & $6 \cdot 96$ & 457 \\
\hline Glu 16 & $125 \cdot 7$ & $57 \cdot 6$ & $174 \cdot 7$ & 8.97 & $4 \cdot 56$ \\
\hline Thr17 & $121-7$ & $61 \cdot 4$ & $172 \cdot 6$ & 8.56 & $5 \cdot 33$ \\
\hline Phel 8 & $127 \cdot 4$ & $55 \cdot 6$ & - & $9 \cdot 41$ & $4 \cdot 34$ \\
\hline Tyrl9 & $124 \cdot 7$ & $57 \cdot 1$ & $176 \cdot 0$ & $9 \cdot 19$ & $5 \cdot 18$ \\
\hline Val20 & 116.0 & $59 \cdot 1$ & $175^{\circ} 0$ & $8 \cdot 40$ & $5 \cdot 60$ \\
\hline Asp21 & 119.0 & $53 \cdot 2$ & $172 \cdot 6$ & $8 \cdot 55$ & 5.05 \\
\hline Gly22 & $108 \cdot 6$ & $45 \cdot 3$ & - & $8 \cdot 28$ & $4 \cdot 94,3 \cdot 50$ \\
\hline Ala23 & 1229 & $52 \cdot 2$ & $175 \cdot 1$ & 8.52 & $4 \cdot 64$ \\
\hline Ala24 & $120 \cdot 5$ & $50 \cdot 4$ & $175 \cdot 2$ & 8.52 & 5.09 \\
\hline Asn25 & $120 \cdot 7$ & $52 \cdot 5$ & $176 \cdot 6$ & - & $4 \cdot 83$ \\
\hline Arg26 & $127 \cdot 6$ & $58 \cdot 8$ & $176^{\circ} 5$ & $9 \cdot 10$ & $4 \cdot 15$ \\
\hline Glu27 & $117 \cdot 4$ & $58 \cdot 6$ & $178: 3$ & 8.41 & $4 \cdot 34$ \\
\hline Thr28 & $107 \cdot 6$ & $61 \cdot 8$ & $176^{\circ} 0$ & 8.06 & $4 \cdot 29$ \\
\hline Lysz9 & 1154 & $58 \cdot 0$ & $173 \cdot 4$ & 808 & 3.89 \\
\hline Leu30 & 118.3 & $54 \cdot 2$ & $177 \cdot 1$ & $7 \cdot 45$ & $4 \cdot 86$ \\
\hline Gly31 & 111.9 & $44 \cdot 8$ & $-\ldots$ & $8 \cdot 02$ & $5 \cdot 03,3 \cdot 61$ \\
\hline Lys32 & -- & $55^{\circ} 0$ & $174 \cdot 0$ & $-\ldots-$ & $5 \cdot 46$ \\
\hline Ala33 & $121 \cdot 6$ & $50 \cdot 0$ & $175 \cdot 5$ & $8 \cdot 49$ & $5 \cdot 27$ \\
\hline Gly34 & $106 \cdot 0$ & $46 \cdot 7$ & $182 \cdot 4$ & $8 \cdot 70$ & $4 \cdot 40,4 \cdot 32$ \\
\hline Tyr35 & $110 \cdot 9$ & $55 \cdot 2$ & $174 \cdot 2$ & 8.48 & $6 \cdot 04$ \\
\hline Val36 & $115 \cdot 2$ & $60 \cdot 9$ & $175 \cdot 5$ & $8 \cdot 69$ & $5 \cdot 24$ \\
\hline Thr37 & 114.5 & $57 \cdot 5$ & $176 \cdot 6$ & $8 \cdot 94$ & $6 \cdot 28$ \\
\hline Asn38 & 1190 & $54 \cdot 2$ & $175 \cdot 4$ & $9 \cdot 05$ & $4 \cdot 62$ \\
\hline Arg39 & $118 \cdot 0$ & $55 \cdot 2$ & $176 \cdot 2$ & $8 \cdot 12$ & $4 \cdot 68$ \\
\hline Gly40 & $107 \cdot 4$ & $45 \cdot 6$ & $174 \cdot 3$ & $7 \cdot 87$ & $4 \cdot 21,3 \cdot 82$ \\
\hline Arg41 & $117 \cdot 7$ & $56 \cdot 3$ & $175 \cdot 1$ & $7 \cdot 20$ & $4 \cdot 71$ \\
\hline Gln42 & $117 \cdot 7$ & $54 \cdot 9$ & $173 \cdot 8$ & $8 \cdot 50$ & $5 \cdot 22$ \\
\hline Lys43 & $123 \cdot 2$ & $56 \cdot 5$ & $172 \cdot 7$ & $7 \cdot 77$ & $4 \cdot 23$ \\
\hline Val44 & $123 \cdot 1$ & $60 \cdot 8$ & 174.5 & $8 \cdot 15$ & 4.90 \\
\hline Val45 & $123 \cdot 6$ & $59-7$ & $174 \cdot 4$ & $9 \cdot 26$ & $4 \cdot 69$ \\
\hline Thr46 & $117 \cdot 9$ & $62 \cdot 0$ & $173 \cdot 8$ & $8 \cdot 41$ & $4 \cdot 96$ \\
\hline Leu47 & $127 \cdot 7$ & $53 \cdot 8$ & $174: 9$ & $8 \cdot 92$ & $4 \cdot 78$ \\
\hline Thr48 & $111 \cdot 3$ & $60 \cdot 2$ & 1735 & $8 \cdot 13$ & $4 \cdot 67$ \\
\hline Asp49 & $121 \cdot 9$ & $55 \cdot 0$ & 174.9 & $8 \cdot 57$ & $4 \cdot 32$ \\
\hline Thr 50 & 1144 & $59 \cdot 8$ & $173 \cdot 6$ & 8.91 & $4 \cdot 88$ \\
\hline Thr5l & $108 \cdot 9$ & $58 \cdot 6$ & 174.9 & $8 \cdot 18$ & $4 \cdot 63$ \\
\hline Asn 52 & 118.5 & $57 \cdot 8$ & 177.0 & $8 \cdot 14$ & $4 \cdot 15$ \\
\hline$G \ln 53$ & $118 \cdot 1$ & 59.9 & $177 \cdot 7$ & 8.59 & $3 \cdot 74$ \\
\hline Lys54 & 1167 & $60 \cdot 6$ & $179 \cdot 4$ & $7 \cdot 44$ & $3 \cdot 88$ \\
\hline Thr55 & 111.5 & $66 \cdot 7$ & $176 \cdot 6$ & $8 \cdot 21$ & $3 \cdot 79$ \\
\hline Glu56 & $121 \cdot 3$ & $59 \cdot 6$ & 179.8 & $7 \cdot 79$ & $3 \cdot 94$ \\
\hline Leu57 & $117 \cdot 6$ & $57 \cdot 5$ & $178 \cdot 6$ & $7 \cdot 53$ & $4 \cdot 06$ \\
\hline Gln58 & $120 \cdot 4$ & $58 \cdot 6$ & $177 \cdot 7$ & $8-90$ & $4 \cdot 02$ \\
\hline Ala 59 & $120 \cdot 6$ & $55 \cdot 8$ & $178 \cdot 4$ & $7 \cdot 93$ & $3 \cdot 99$ \\
\hline Ile60 & $115 \cdot 2$ & 65.5 & $176 \cdot 9$ & 6.91 & $3 \cdot 49$ \\
\hline Tyr61 & 119.4 & $61 \cdot 2$ & $176 \cdot 8$ & $8 \cdot 17$ & $4 \cdot 03$ \\
\hline Leu62 & 118.5 & $57 \cdot 7$ & 177.9 & $8: 5 i$ & $3 \cdot 84$ \\
\hline Ala63 & $117 \cdot 6$ & $53 \cdot 8$ & $179 \cdot 3$ & $7 \cdot 24$ & $3 \cdot 27$ \\
\hline Leu64 & 116.8 & $57 \cdot 6$ & $177 \cdot 6$ & $7 \cdot 72$ & $3 \cdot 37$ \\
\hline$(9 \ln 65$ & 117.5 & $59 \cdot 0$ & $178 \cdot 3$ & $8 \cdot 21$ & $3 \cdot 69$ \\
\hline Asp66 & $115 \cdot 4$ & $54 \cdot 5$ & $175 \cdot 1$ & $7 \cdot 45$ & $4 \cdot 74$ \\
\hline Ser67 & $112 \cdot 9$ & $56 \cdot 1$ & $175 \cdot 7$ & $7 \cdot 05$ & $4 \cdot 54$ \\
\hline Gly 68 & $104 \cdot 6$ & $43 \cdot 8$ & 173.8 & $8 \cdot 32$ & - \\
\hline Leu69 & 117.7 & $57 \cdot 6$ & 176.4 & $8 \cdot 35$ & $4 \cdot 07$ \\
\hline
\end{tabular}

Table 1 (continued)

\begin{tabular}{|c|c|c|c|c|c|}
\hline & \multicolumn{5}{|c|}{ Chemical shift (p.p.m.) $\dagger$} \\
\hline & ${ }^{15} \mathrm{~N}$ & & & NH & $C^{\alpha} \mathbf{H}$ \\
\hline Glu70 & 115.2 & $53 \cdot 7$ & $174 \cdot 8$ & $7 \cdot 57$ & $5 \cdot 83$ \\
\hline Val71 & $119 \cdot 6$ & $61 \cdot 1$ & $169 \cdot 9$ & 8.06 & $4 \cdot 64$ \\
\hline Asn72 & $122 \cdot 8$ & 51.8 & $174 \cdot 0$ & 7.92 & 5.93 \\
\hline Ile73 & $125 \cdot 2$ & $61 \cdot 1$ & -- & $9 \cdot 75$ & $-\ldots$ \\
\hline Val74 & $126 \cdot 2$ & $60 \cdot 6$ & $175 \cdot 4$ & $8 \cdot 93$ & 500 \\
\hline Thr75 & $120 \cdot 4$ & $58 \cdot 1$ & $171 \cdot 6$ & $8 \cdot 76$ & $5 \cdot 18$ \\
\hline Asp76 & & & $-\cdots$ & $\ldots \ldots$ & - \\
\hline Ser77 & - & 56.9 & 174.8 & & $4 \cdot 63$ \\
\hline Gln78 & $128 \cdot 6$ & $58 \cdot 2$ & - & $8 \cdot 70$ & 3.96 \\
\hline Tyr79 & $120 \cdot 3$ & $60 \cdot 2$ & 176.9 & $8 \cdot 40$ & $4 \cdot 26$ \\
\hline Ala80 & $121 \cdot 6$ & $54 \cdot 7$ & $178 \cdot 8$ & $8 \cdot 40$ & $3 \cdot 59$ \\
\hline Leu8I & 114.9 & $57 \cdot 9$ & $178 \cdot 6$ & 7.54 & $3 \cdot 80$ \\
\hline Gly82 & $104 \cdot 5$ & $46 \cdot 7$ & 1766 & 7.90 & 3.80 \\
\hline Ile83 & 120.7 & $62 \cdot 9$ & $177 \cdot 3$ & $7 \cdot 39$ & 3.84 \\
\hline Ile84 & 117.5 & $64 \cdot 2$ & 178.0 & $7 \cdot 39$ & $3 \cdot 65$ \\
\hline Gln85 & 116.7 & $57 \cdot 4$ & $176 \cdot 2$ & $8 \cdot 03$ & $4 \cdot 42$ \\
\hline Ala86 & $121 \cdot 0$ & $52 \cdot 5$ & $176 \cdot 4$ & $7 \cdot 38$ & $4 \cdot 35$ \\
\hline Gln87 & 115.9 & $55 \cdot 0$ & $173 \cdot 1$ & 7.95 & $4 \cdot 40$ \\
\hline Pro88 & - & $63 \cdot 4$ & 176.5 & $\cdots$ & $4 \cdot 43$ \\
\hline Asp89 & $119 \cdot 0$ & $54 \cdot 1$ & $176 \cdot 3$ & $8 \cdot 37$ & $4 \cdot 61$ \\
\hline Gln 90 & 118.5 & $56 \cdot 3$ & $175 \cdot 7$ & $8 \cdot 21$ & 4.32 \\
\hline Ser91 & 115.5 & $59 \cdot 0$ & 174.9 & $8 \cdot 50$ & $4 \cdot 40$ \\
\hline Glu92 & $122 \cdot 2$ & $56 \cdot 6$ & $176 \cdot 3$ & $8 \cdot 34$ & $4: 39$ \\
\hline Ser93 & $114 \cdot 4$ & $58 \cdot 5$ & 1751 & 7.98 & 4.31 \\
\hline Glu94 & 1267 & $59 \cdot 6$ & 178.0 & $8 \cdot 76$ & $4 \cdot 10$ \\
\hline Leu95 & $120 \cdot 0$ & $57 \cdot 4$ & 178.5 & $7 \cdot 84$ & $4 \cdot 10$ \\
\hline Val96 & 117.9 & $67 \cdot 6$ & 177.4 & $7 \cdot 68$ & $3 \cdot 37$ \\
\hline Asn97 & $117 \cdot 2$ & $\mathbf{5 6} 8$ & $178 \cdot 1$ & $8 \cdot 00$ & $\mathbf{4} \cdot 40$ \\
\hline Gln98 & $119 \cdot 9$ & $59 \cdot 1$ & $179 \cdot 2$ & 8.07 & 4.07 \\
\hline Ile99 & $121 \cdot 7$ & $66 \cdot 3$ & $177 \cdot 3$ & $8 \cdot 06$ & 3.52 \\
\hline Ile100 & $121 \cdot 3$ & $65 \cdot 9$ & $177 \cdot 1$ & 8.53 & $3 \cdot 36$ \\
\hline Glul01 & $116 \cdot 7$ & $59 \cdot 6$ & $179 \cdot 2$ & 7.91 & $3 \cdot 93$ \\
\hline Gln102 & $114 \cdot 5$ & $57 \cdot 7$ & $178 \cdot 6$ & $7 \cdot 46$ & 3.94 \\
\hline Leu 103 & $120 \cdot 9$ & $58 \cdot 6$ & $179 \cdot 3$ & $8 \cdot 42$ & $3 \cdot 58$ \\
\hline Ile104 & $115 \cdot 3$ & $64 \cdot 7$ & 1766 & $7 \cdot 91$ & 379 \\
\hline Lys105 & 116.6 & $57 \cdot 1$ & 177.6 & $6 \cdot 97$ & $4 \cdot 22$ \\
\hline Lys 106 & 116.5 & $54 \cdot 3$ & 176.8 & $7 \cdot 19$ & 4.27 \\
\hline Glul07 & $120 \cdot 8$ & 58.5 & 177.7 & $9 \cdot 03$ & $4 \cdot 37$ \\
\hline Lys108 & 114.8 & $56 \cdot 1$ & $174 \cdot 1$ & $7 \cdot 69$ & 4.93 \\
\hline Vallog & $121 \cdot 2$ & $60 \cdot 3$ & 172.7 & $9 \cdot 07$ & 4.98 \\
\hline Tyr110 & $129 \cdot 6$ & $56 \cdot 3$ & $172 \cdot 2$ & $8 \cdot 44$ & $4 \cdot 80$ \\
\hline Leul11 & $129 \cdot 1$ & $52 \cdot 8$ & $174 \cdot 0$ & 7.93 & $5 \cdot 31$ \\
\hline Ala112 & $125 \cdot 1$ & 50.9 & $174 \cdot 2$ & $8 \cdot 38$ & $4 \cdot 32$ \\
\hline Alal13 & $120 \cdot 8$ & $49 \cdot 6$ & $177 \cdot 8$ & 8.21 & 5.50 \\
\hline Vall14 & $\cdots$ & $\cdots$ & - & $\ldots$ & $\cdots$ \\
\hline Prolls & $\cdots$ & $\ldots$ & --- & $\cdots$ & $\cdots$ \\
\hline Ala 116 & - & - & - & & - \\
\hline Hisl17 & $\cdots$ & - & - & $\cdots$ & - \\
\hline Lys118 & 119.4 & $58 \cdot 5$ & $178 \cdot 2$ & $7 \cdot 74$ & 4.06 \\
\hline Gly119 & -- & $45 \cdot 4$ & $\ldots$ & -- & $4 \cdot 03,3 \cdot 83$ \\
\hline Ilel20 & 119.5 & $60 \cdot 9$ & 17688 & $7 \cdot 87$ & $4 \cdot 15$ \\
\hline Glyl21 & 113.8 & $45 \cdot 6$ & $175 \cdot 0$ & $8 \cdot 66$ & $3 \cdot 93$ \\
\hline Gly 122 & $108 \cdot 8$ & - & - & $8 \cdot 13$ & - \\
\hline Asnl23 & $\cdots$ & $53 \cdot 8$ & $174 \cdot 2$ & $-\cdots$ & $4 \cdot 61$ \\
\hline Glu124 & $120 \cdot 5$ & 57.0 & $175 \cdot 6$ & 8.57 & $4 \cdot 24$ \\
\hline Gln125 & -- & - & $\cdots$ & $\cdots$ & -. \\
\hline Vall26 & & $\ldots$ & - & & - \\
\hline Aspl27 & --- & - & $\cdots . .$. & & - \\
\hline Lysl28 & & ... & - & $\ldots$ &.- \\
\hline Leu 129 & $\ldots$ & - & - & $-\cdots$ & $\ldots$ \\
\hline Vall30 & $\cdots$ & $\ldots$ & -- & $\ldots$ & - \\
\hline Ser131 & --- & - & -- & & $\cdots$ \\
\hline Ala 132 &.-- & $\ldots$ & $\ldots-. .-$ & $\cdots-$. & - \\
\hline Glyl33 & $110 \cdot 0$ & $45 \cdot 2$ & $178 \cdot 0$ & $8 \cdot 59$ & $3 \cdot 95,3 \cdot 80$ \\
\hline Ile134 & $119 \cdot 7$ & $64 \cdot 3$ & 177.0 & $8 \cdot 03$ & $4 \cdot 22$ \\
\hline Arg135 & $114 \cdot 0$ & $55 \cdot 8$ & $175 \cdot 4$ & $7 \cdot 10$ & $4 \cdot 40$ \\
\hline Lys136 & $122 \cdot 7$ & $56 \cdot 3$ & $175 \cdot 7$ & $8 \cdot 25$ & $4 \cdot 35$ \\
\hline Vall 37 & $122 \cdot 3$ & $62 \cdot 4$ & 174.9 & $8 \cdot 15$ & $4 \cdot 11$ \\
\hline Leul38 & $130 \cdot 6$ & 566 & - & $7 \cdot 83$ & $4 \cdot 20$ \\
\hline
\end{tabular}

$\dagger^{1} \mathrm{H}$ and ${ }^{13} \mathrm{C}$ chemical shifts are expressed relative to (trimethylsilyl)-propionic- $\mathrm{d}_{4}$ acid, and ${ }^{15} \mathrm{~N}$ shifts relative to liquid $\mathrm{NH}_{3}$. 


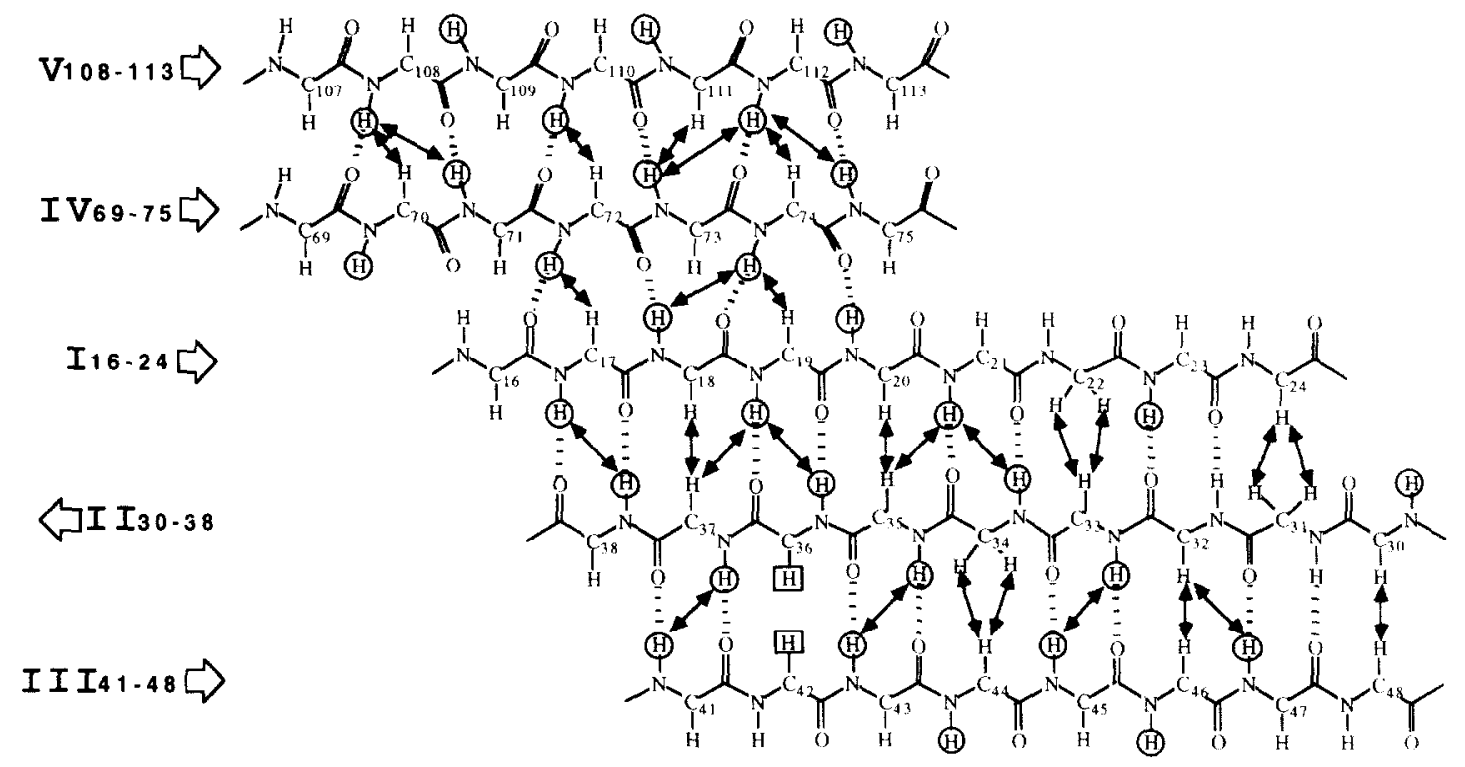

Figure 4. $\beta$-Sheet structure of Trpl13 $\rightarrow$ Ala RNase $\mathrm{H}$ from HIV-1 as determined from a qualitative analysis of NOE and amide exchange data. The $\beta$-strands are indicated on the left by roman numerals and the residue number range. Long-range NOEs are indicated by arrows, and hydrogen bonds derived from the $\mathrm{NH} /$ solvent exchange and NOE data are shown as broken lines. The slowly exchanging amide protons are encircled. The ${ }^{1} \mathrm{H}$ chemical shifts of the $C^{\alpha} I I$ protons of Val36 and Glu42 are degenerate and indicated by a square box around them.

obtained by recording a series of ${ }^{15} \mathrm{~N}-{ }^{1} \mathrm{H}$ Overbodenhausen correlation spectra (Bax et al., $1990 a$ ) over a period of 80 hours starting within five minutes of dissolving an unexchanged sample of lyophilized protein in ${ }^{2} \mathrm{H}_{2} \mathrm{O}$ (Driscoll et $\mathrm{al}$, 1990b). We find threc clearly defined helices, which extend from residues 52 to $66\left(\alpha_{A}\right), 78$ to $87\left(\alpha_{B}\right)$ and 93 to $106\left(\alpha_{D}\right)$, and five $\beta$-strands from residues 16 to 24 (strand I), 30 to 38 (strand II), 41 to 48 (strand III), 69 to 75 (strand IV) and 108 to 113 (strand V). These five strands form a mixed parallel-antiparallel $\beta$-sheet, which is illustrated in Figure 4. Strands I, II and III are antiparallel and connected via a short loop and $\beta$-turn, respectively. Strand I is parallel to strand IV, which in turn is parallel to strand $V$. The connecting element between strands III and IV is formed by $\alpha$-helix $\alpha_{A}$ while that between strands IV and $V$ is formed by the other two helices, $\alpha_{B}$, and $\alpha_{D}$. Thus, using the notation of Richardson (1981), the topolngy of the sheet can be described as $+1,+1,-3 x,-1 x$. It is interesting to note that the slowest exchanging amide protons are located in strands I, IV and $\mathrm{V}$ and helices $\alpha_{A}$ and $\alpha_{D}$. Further, while there is an extensive network of NOE connectivities between strands I, II and III and between strands IV and V, the number of NOE connectivities between strands I and IV is very limited and their intensities are weak. The latter may be due to fraying at the ends of these two strands, accompanied by conformational mobility. Taken together, these observations suggest that $\beta$-strands $\mathrm{IV}$ and $\mathrm{V}$ and the connecting $\alpha$-helices $\alpha_{\mathrm{A}}$ and $\alpha_{\mathrm{D}}$ constitute the most tightly folded portion of the RNase $H$ structure.

The last well-defined residue in solution is Alal13, and the C-terminal region from Vall14 to Glyl33 appears to be conformationally disordered as evidenced by an almost complete absence of sequential and medium range NOEs (Fig. 3). In the X-ray structure residues 116 to 120 are also disordered and not visible in the electron density map. However, there is a helix $\left(\alpha_{E}\right)$ from Glyl21 to Serl31 in the $\mathrm{X}$-ray structure, which is absent in solution. This is probably due to greater conformational flexibility in the solution state and implies that this helix is not required to stabilize the overall polypeptide fold

It should be noted that carboxy-terminal proteolytic cleavage of the RNase $H$ domain results in a polypeptide approximately $3000 \mathrm{Da}$ smaller than the native form (P.T. Wingfield, A.M. Gronenborn, G. M. Clore, unpublished results). This shortened cleavage product no longer exhibits a folded structure, as judged by both c.d. and n.m.r. spectra, which are characteristic of a random coil conformation. The most likely location of the cleavage site is in the sequence I.ys105-I.ys106Glu107-Lys108. located at the beginning of $\beta$-strand $V$. Thus, removal of part or all of $\beta$-strand $V$ destroys the folded form of RNase $H$. which is consistent with the above interpretation.

With the exception of the C-terminal helix $\alpha_{E}$. which is not observed in solution, the secondary structure found in the liquid and crystal states are in agreement. It should be pointed out that the RNase $H$ domains studied by n.m.r. and crystallography were derived from two different HIV-] strains, $\mathrm{HXB} 2$ and $\mathrm{BH} 10$, respectively, and differ by several amino acid substitutions (i.e. Ile $46 \rightarrow$ Pro, Asp49 $\rightarrow$ Asn, Gln90 $\rightarrow$ Lys and Vall37 $\rightarrow$ Ile). In addition, the sequence of the protein used for the n.m.r. studies contains the engineered Trpl13 $\rightarrow$ Ala mutation and the tetrapeptide Met-Asn-Glu-Leu 
appended at the $\mathrm{N}$ terminus, while these four residues in the crystallized protein are Tyr-Ala-Ser-Arg. With the exception of the Ile46 $\rightarrow$ Pro change, which is located at the end of strand III, the differences are conservative, located in loops or at the disordered $\mathrm{N}$ and $\mathrm{C}$ termini, and clearly do not affect the structure in any significant manner.

Comparison of the secondary structure of HIV-1 RNase $H$ with that of $E$. coli (Yang et al., 1990; Katayanagi et al., 1990; Yamazaki et al., 1991) is also of interest. There is an almost perfect match of the five $\beta$-strands and helices $\alpha_{A}, \alpha_{B}$ and $\alpha_{D}$ between HIV-1 and E. coli RNase H. The $\alpha_{\mathrm{B}}$ helix in the HIV-1 RNase $H$ is about two to three residues longer than that of the corresponding helix in the $E$. coli enzyme, and the $\alpha_{C}$ helix and the subsequent 12-residue loop that serve to connect helices $\alpha_{B}$ and $\alpha_{\mathrm{D}}$ in the $E$. coli protein are replaced by a short loop comprising residues 88 to 92 in the HIV-1 enzyme.

In summary we have made use of $3 \mathrm{D}$ double and triple resonance heteronuclear n.m.r. spectroscopy to obtain ${ }^{1} \mathrm{H},{ }^{15} \mathrm{~N}$ and ${ }^{13} \mathrm{C}$ backbone sequential assignments for the RNase $\mathrm{H}$ domain of $\mathrm{HIV}-1$ reverse transcriptase. The observed secondary structure in solution is consistent with that found in the crystal structure but there appears to be substantially more disorder at the $\mathrm{C}$ terminus in the solution structure. Further, extensive line broadening in the n.m.r. spectra of the wild-type protein is strongly suggestive of extensive conformational heterogeneity, which is in part alleviated by the mutation of Trp113 to Ala.

This work was supported by the AIDS Targeted Anti-viral Program of the Office of the Director of the National Institutes of Health. We thank Joshua Kaufman and I'a Palmer for technicul assistance with the protein purification, and Joseph Shiloah for fermentations.

\section{References}

Bax. A., Ikura, M., Kay, L. E., Torchia, D. A. \& Tschudin, R. (1990a). Comparison of different modes of two-dimensional reverse correlation NMR for the study of proteins. J. Magn. Reson. 86, 304-318.

Bax. A., Clore, G. M., Driscoll, P. C., Gronenborn, A. M., Ikura, M. \& Kay, L. E. (1990b). Practical aspects of proton-carbon-carbon-proton three-dimensional correlation spectroscopy of ${ }^{13} \mathrm{C}$-labeled proteins. J. Magn. Reson. 87, 620-628.

Bax, A., Clore, G. M. \& Gronenborn, A. M. (1990c). ${ }^{1} \mathrm{H}^{1}{ }^{1} \mathrm{H}$ correlation via isotropic mixing of ${ }^{13} \mathrm{C}$ magnetization: a new three-dimensional approach for assigning ${ }^{1} \mathrm{H}$ and ${ }^{13} \mathrm{C}$ spectra of ${ }^{13} \mathrm{C}$-enriched proteins. J. Magn. Reson. 88, 425-431

Becerra, S. P.. Clore, G. M., Gronenborn, A. M., Karlström, A., Stahl, S. J., Wilson, S. H. \& Wingfield, P. T. (1990). Purification and characterization of the RNase $\mathrm{H}$ domain of HIV-1 reverse transcriptase expressed in recombinant Escherichia coli. FEBS Letters, 270, 76-80.

Bodenhausen, G. \& Ruben, D. J. (1980). Natural abundance nitrogen-15 NMR by enhanced heteronuclear spectroseopy. Chem. Phys. Letters, 69 185-189.

Clore, G. M. \& Gronenborn, A. M. (1987). Determination of three-dimensional structures of proteins in solution by nuclear magnetic resonance spectroseopy. Protein Engineer. 1, 275-288.

Clore, G. M. \& Gronenborn, A. M. (1991 $a)$. Structures of larger proteins in solution: three- and fourdimensional heteronuclear NMR spectroscopy. Science, 252, 1390-1399.

Clore, G. M. \& Gronenborn, A. M. (1991b). Two, three and four-dimensional NMR methods for obtaining larger and more precise three-dimensional structures of proteins in solution. Annu. Rev. Biophys. Biophys. Chem. 20, 29-63.

Clore, G. M. \& Gronenborn, A. M. (1991c). Applications of three- and four-dimensional heteronuclear NMR spectroscopy to protein structure determination. Progr. Nucl. Magn. Reson. 23, 43-92.

Clore, G. M., Bax, A., Driscoll, P. C., Wingfield, P. T. \& Gronenborn, A. M. (1990). Assignment of the side chain ${ }^{1} \mathrm{H}$ and ${ }^{13} \mathrm{C}$ resonances of interleukin- $\beta$ using double and triple resonance heteronuclear threedimensional NMR spectroscopy. Biochemistry, 29 , $8172-8184$.

Clore, G. M., Bax, A. \& Gronenborn, A. M. (1991). Stereospecific assignment of $\beta$-methylene protons using three-dimensional ${ }^{15} \mathrm{~N}$-separated HartmannHahn and ${ }^{13} \mathrm{C}$-separated rotating frame Overhauser spectroscopy. J. Biomol. NMR, 1, 13-22

Davies, J. F., Hostomska, Z., Iostomsky, Z.. Jordan, S. R. \& Matthews, D. A. (1991). Crystal structure of the ribonuclease $\mathrm{H}$ domain of $\mathrm{HIV}-1$ reverse transcriptase. Science, 252, 88-95.

Driscoll, P. C., Clore, G. M., Marion, I)., Wingfield, P. T. \& Gronenborn, A. M. (1990a). Complete resonance assignment for the polypeptide backbone of interleukin- $1 \beta$ using three-dimensional heteronuclear NMR spectroscopy. Biochemistry, 29, 3542-3556

Driscoll, P. C., Gronenborn, A. M., Wingfield, P. T. \& Clore, G. M. (1990b). Determination of the secondary structure and molecular topology of interleukin-l $\beta$ using two- and three-dimensional heteronuclear ${ }^{15} \mathrm{~N}^{-1} \mathrm{H}$ NMR spectroscopy. Biochemistry, 29 4468-4682.

Fesik, S. W. \& Zuiderweg, E. R. P. (1988). Heteronuclear three-dimensional NMR spectroscopy: a strategy for the simplification of homonuclear two-dimensional NMR spectra. J. Magn. Reson. 78, 588-593.

Garrett, D. S., Powers, R., Gronenborn. A. M. \& Clore G. M. (1991). A common sense approach to peak picking using two, three- and four-dimensional contour diagrams for automated computer analysis. J. Magn. Reson. In the press.

Ikura, M. \& Bax, A. (1991). An efficient three-dimensional NMR technique for correlating the proton and nitrogen-15 backbone amide resonance with the alpha carbon of the preceeding residue in uniformly ${ }^{15} \mathrm{~N}-{ }^{13} \mathrm{C}$ enriched proteins. J. Biomol. NMR. 1 99-104.

Ikura, M., Kay, L. E. \& Bax, A. (1990a). A nove approach for sequential assignment of ${ }^{1} \mathrm{H},{ }^{13} \mathrm{C}$ and ${ }^{15} \mathrm{~N}$ spectra of larger proteins: heteronuclear tripleresonance three-dimensional NMR spectroscopy Application to calmodulin. Biochemistry, 29 4659-4667.

Ikura, M., Kay, L. E., Tschudin, R. \& Bax, A. (1990b) Three-dimensional NOESY-HMQC spectroscopy of a ${ }^{13}$ C-labeled protein. J. Magn. Reson. 86, 204-209. 
Katayanagi, K., Miyagawa, M., Matsushima, M. Ishikawa, M., Kanaya, S., Ikehara, M., Matsuzaki, T. \& Morikawa, K. (1990). 'Three-dimensional structure of ribonuclease $\mathbf{H}$ from $E$. coli. Nature (London), 347 , 306-309.

Kay, L. E., Marion, D. \& Bax, A. (1989). Practical aspects of 3D heteronuclear NMR of proteins. J. Magn. Reson. 84, 72-84.

Kay, L. E., Ikura, M. \& Bax, A. (1990a). Proton-proton correlation via carbon-carbon couplings: a threedimensional NMR approach for the assignment of aliphatic resonances in proteins labeled with carbon13. J. Amer. Chem. Soc. 112, 888-889.

Kay, L. E., Ikura, M., Tschudin, R. \& Bax, A. (1990b). Three-dimensional triple resonance NMR spectroscopy of isotopically enriched proteins. J. Magn. Reson. 89, 496-514.

Krug, M. S. \& Berger, S. L. (1989). Ribonuclease H activities associated with viral reverse transcriptases are endonucleases. Proc. Nat. Acad. Sci. U.S.A. 86 $3539-3543$.

Marion, D., Kay, L. E., Sparks, S. W., Torchia, D. A. \& Bax, A. $(1989 a)$. Three-dimensional heteronuclear NMR of ${ }^{15} \mathrm{~N}$ labeled proteins. J. Amer. Chem. Soe. 111, 1515-1517.

Marion, D., Driscoll, P. C., Kay, L. E., Wingfield, P. T. Bax, A., Gronenborn, A. M. \& Clore, G. M. (1989b) Overcoming the overlap problem in the assignment of ${ }^{1} \mathrm{H}$-NMR spectra of larger proteins using threedimensional heteronuclear ${ }^{1} \mathrm{H}^{-1}{ }^{15} \mathrm{H}$ Hartmann-Hahn and nuclear Overhauser multiple quantum coherence spectroscopy: application to interleukin- $\beta$ Biochemistry, 28, 6150-6156

Mitsuya, H., Yarchoan, K. \& Broder, S. (1990). Molecular targets for AIDS therapy. Science, 249, 1533-1544.

Mizrahi, V. (1989) Analysis of ribonuclease $H$ activity of HIV-1 reverse transcriptase using RNA/DNA hybrid substrates derived from the gag region of HIV-1. Biochemistry, 28, 9088-9094.

Oostraa, B. M., Harvey, R., Ely, B. K., Markham, A. F. \& Smith, A. E. (1983). Transforming activity of polyoma virus middle- $\mathrm{T}$ antigen probed by sitedirected mutagenesis. Nature (London), 304 456-459.

Powers, R., Gronenborn, A. M., Clore, G. M. \& Bax, A (1991). Three-dimensional triple resonance. NMR of ${ }^{13} \mathrm{C} /{ }^{15} \mathrm{~N}$ enriched proteins using constant-time evolution. J. Magn. Reson. 94, 209-213.

Richardson, J. S. (1981). The anatomy and taxonomy of protein structure. Advan. Protein Chem. 34, 167-339

Schatz, O., Cromme, F. V., Grünniger-Leitch, F. \& LeGrice, S. F. J. (1989). Point mutations in conserved amino acid residues within the C-terminal domain of HIV-1 reverse transcriptase specifically repress $\mathrm{RNase} \mathrm{H}$ function. FEBS. Letters, 257 , $311-314$

Schatz, O., Mous, J. \& LeGrice, S. F. J. (1990). HIV-1 RT-associated ribonuclease $\mathrm{H}$ displays both endonuclease and $3^{\prime} \rightarrow 5^{\prime}$ exonuclease activity. EMBO J. 9,1171-1176.

Wüthrich, K. (1986). NMR of Proteins and Nucleic Acids, John Wiley, New York.

Yamazaki, T., Yoshida, M., Kanaya, S., Nakamura, H.\& Nagayama, K. (1991). Assignment of the backbone ${ }^{1} \mathrm{H},{ }^{13} \mathrm{C}$ and ${ }^{15} \mathrm{~N}$ resonances and secondary structure of ribonuclease H from Escherichia coli by heteronuclear three-dimensional NMR spectroscopy. Biochemistry, 30, 6036-6047.

Yang, W., Hendrickson, W. A., Crouch, R. J. \& Satow, Y (1990). Structure of ribonuclease $H$ phased at $2 \AA$ resolution by $\mathrm{MAD}$ analysis of the selenomethyonyl protein. Science, 249, 1398-1405.

Zhu, G. \& Bax, A. (1990). Improved linear prediction for truncated signals of known phase. J. Magn. Reson. $90,405-410$

Zuiderweg, E. R. P., McIntosh, L. P., Dahlquist, F. W. \& Fesik, S. W. (1990). Three-dimensional ${ }^{13} \mathrm{C}$-resolved proton NOE spectroscopy of uniformly ${ }^{13} \mathrm{C}$-labeled proteins for NMR assignment and structure determination of larger molecules. I. Magn. Reson. 86, $210-216$ 